\title{
Occurrence of the rust resistance gene Lr37 from Aegilops ventricosa in Argentine cultivars of wheat
}

\author{
Mariano Bulos \\ Department of Biotechnology \\ Nidera S.A. \\ Casilla de Correo 6 \\ 2600 Venado Tuerto \\ Santa Fe, Argentina \\ Tel: 543462421944 \\ Fax: 543462423196 \\ E-mail: mbulos@nidera.com.ar \\ Mariel Echarte \\ Department of Biotechnology \\ Nidera S.A. \\ Casilla de Correo 6 \\ 2600 Venado Tuerto \\ Santa Fe, Argentina \\ E-mail: mecharte@nidera.com.ar \\ Carlos Sala* \\ Department of Biotechnology \\ Nidera S.A. \\ Casilla de Correo 6 \\ 2600 Venado Tuerto \\ Santa Fe, Argentina \\ Tel: 543462423196 \\ E-mail: csala@nidera.com.ar
}

Keywords: diversity, marker assisted selection, Puccinia triticina, Triticum aestivum, translocation.

Leaf rust of wheat (Triticum aestivum $\mathrm{L}$.) caused by the fungus Puccinia triticina (formerly $P$. recondita $f$. sp. tritici), is one of the most important foliar diseases of this crop. $L r 37$ rust resistance gene, which confers resistance in wheat against leaf rust, was introgressed into cultivated wheat from Aegilops ventricosa Tausch. Rust races with virulence to $\operatorname{Lr} 37$ have been identified in different countries, but it still provides resistance to a wide range of races and is useful in combination with other resistance genes. There are no reports about the presence, frequency and origin of Lr37 in Argentinean wheat cultivars. In this work, we analyzed 88 registered Argentinean wheat cultivars developed by different breeding companies and institutions during the last $\mathbf{1 5}$ years by means of a molecular marker which is diagnostic of the 2NS-2AS translocation which carries Lr37. Only 4 cultivars showed the amplification product associated with this chromosome fragment. These four cultivars which carry the translocated 2NS-2AS chromosome were registered by the same breeding company during the last seven years and all of them have European germplasm in their genealogy. To the best of our knowledge this is the first report of the presence of $\mathrm{Lr} 37$ in registered South American cultivars.

Leaf rust of wheat (Triticum aestivum L.) caused by the fungus Puccinia triticina (formerly $P$. recondita $f$. sp. tritici), is one of the most important foliar diseases of this crop. Breeding wheat cultivars with resistance to leaf rust is the most effective, economical and environmentally friendly method of disease control and was used in numerous wheat breeding programs worldwide (Kolmer, 1996). However, a gene-for-gene interaction exists between host resistance genes and pathogen avirulence genes in the wheat- $P$. triticina pathosystem and virulence shifts in the pathogen populations have reduced the effectiveness of a number of leaf rust resistance genes (Johnson, 2000), which increased the search of new resistant genes, not only in the cultivated gene-pool, but also in the wild relatives of wheat (Friebe et al. 1996; Valkoun, 2001).

The wild wheat species, Aegilops ventricosa Tausch (syn.

* Corresponding authors 
Table 1. Utilized materials, year of registration, breeding companies or institutions and presence of the 2NS diagnostic PCR marker for Lr37.

\begin{tabular}{|c|c|c|c|}
\hline Cultivar & Registration Year ${ }^{(1)}$ & Registrated or Commercializated by & $\begin{array}{c}\text { Presence of the } \\
\text { marker for Lr37 }\end{array}$ \\
\hline ACA223 & 2000 & $\mathrm{ACA}^{(3)}$ & - \\
\hline ACA302 & 2002 & ACA & - \\
\hline ACA303 & 2002 & ACA & - \\
\hline ACA304 & 2004 & ACA & - \\
\hline ACA601 & 2003 & ACA & - \\
\hline ACA801 & 2004 & ACA & - \\
\hline Cooperacion Maipun & 1994 & ACA & - \\
\hline Zorzal & 2003 & ACA & - \\
\hline Baguette 10 & 1999 & Nidera S.A. & + \\
\hline Baguette 12 & 1999 & Nidera S.A. & + \\
\hline Baguette 19 & 2005 & Nidera S.A. & - \\
\hline Baguette 20 & 2004 & Nidera S.A. & - \\
\hline Baguette 21 & 2003 & Nidera S.A. & - \\
\hline Baguette Premium 11 & 2004 & Nidera S.A. & + \\
\hline Baguette Premium 13 & 2001 & Nidera S.A. & - \\
\hline Baguette Sur 15 & 2001 & Nidera S.A. & - \\
\hline Baguette Sur 22 & 2004 & Nidera S.A. & - \\
\hline Baguette Sur 23 & 2004 & Nidera S.A. & - \\
\hline Baguette Sur 24 & 2004 & Nidera S.A. & - \\
\hline Baguette Sur 5 & 2001 & Nidera S.A. & + \\
\hline Triguero 100 & 1998 & Nidera S.A. & - \\
\hline Triguero 230 & 1997 & Nidera S.A. & - \\
\hline BioInta 1000 & 2004 & INTA / Bioceres & - \\
\hline BioInta 1001 & 2004 & INTA / Bioceres & - \\
\hline BioInta 3003 & 2004 & INTA / Bioceres & - \\
\hline BioInta Bonaerense 2001 & 2004 & INTA / Bioceres & - \\
\hline BioInta3000 & 2004 & INTA / Bioceres & - \\
\hline Buck Aguara & 2004 & Buck Semillas S.A. & - \\
\hline Buck Antorcha & 1997 & Buck Semillas S.A. & - \\
\hline Buck Arriero & 1998 & Buck Semillas S.A. & - \\
\hline Buck Bigua & 2002 & Buck Semillas S.A. & - \\
\hline Buck Brasil & 2000 & Buck Semillas S.A. & - \\
\hline Buck Candil & 1994 & Buck Semillas S.A. & - \\
\hline Buck Catriel & 1992 & Buck Semillas S.A. & - \\
\hline Buck Chacarero & 2005 & Buck Semillas S.A. & - \\
\hline Buck Farol & 2000 & Buck Semillas S.A. & - \\
\hline Buck Guapo & 2000 & Buck Semillas S.A. & - \\
\hline Buck Guatimozin & 2001 & Buck Semillas S.A. & - \\
\hline Buck Halcon & 1999 & Buck Semillas S.A. & - \\
\hline Buck Mataco & 2002 & Buck Semillas S.A. & - \\
\hline Buck Mejorpan & 2004 & Buck Semillas S.A. & - \\
\hline
\end{tabular}


Occurrence of the rust resistance gene Lr37 from Aegilops ventricosa in Argentine cultivars of wheat

\begin{tabular}{|c|c|c|c|}
\hline Buck Palenque & 1991 & Buck Semillas S.A. & - \\
\hline Buck Panadero & 1998 & Buck Semillas S.A. & - \\
\hline Buck Pingo & 2002 & Buck Semillas S.A. & - \\
\hline Buck Pronto & 1997 & Buck Semillas S.A. & - \\
\hline Buck Sureño & 2000 & Buck Semillas S.A. & - \\
\hline Buck Yatasto & 1998 & Buck Semillas S.A. & - \\
\hline Caudillo & 1998 & Buck Semillas S.A. & - \\
\hline Cronox & 2005 & Don Mario S.A. & - \\
\hline Onix & 2004 & Don Mario S.A. & - \\
\hline INIA Tijereta & 2001 & Relmo S.A. & - \\
\hline Greina & 1998 & Relmo S.A. & - \\
\hline Lona & 1997 & Relmo S.A. & - \\
\hline Klein Cacique & 1991 & Criadero Klein S.A. & - \\
\hline Klein Capricornio & 2004 & Criadero Klein S.A. & - \\
\hline Klein Castor & 2005 & Criadero Klein S.A. & - \\
\hline Klein Chaja & 2002 & Criadero Klein S.A. & - \\
\hline Klein Delfin & 2000 & Criadero Klein S.A. & - \\
\hline Klein Don Enrique & 1998 & Criadero Klein S.A. & - \\
\hline Klein Dragon & 1993 & Criadero Klein S.A. & - \\
\hline Klein Escorpion & 1999 & Criadero Klein S.A. & - \\
\hline Klein Escudo & 2000 & Criadero Klein S.A. & - \\
\hline Klein Estrella & 1996 & Criadero Klein S.A. & - \\
\hline Klein Flecha & 2003 & Criadero Klein S.A. & - \\
\hline Klein Gavilan & 2004 & Criadero Klein S.A. & - \\
\hline Klein Jabali & 2002 & Criadero Klein S.A. & - \\
\hline Klein Martillo & 2001 & Criadero Klein S.A. & - \\
\hline Klein Pegaso & 1997 & Criadero Klein S.A. & - \\
\hline Klein Proteo & 2003 & Criadero Klein S.A. & - \\
\hline Klein Sagitario & 2000 & Criadero Klein S.A. & - \\
\hline Klein Tauro & 2005 & Criadero Klein S.A. & - \\
\hline Klein Volcan & 1998 & Criadero Klein S.A. & - \\
\hline Prointa Alazan & 1997 & $\operatorname{INTA}^{(4)}$ & - \\
\hline ProInta Calidad & 2000 & INTA & - \\
\hline ProInta Colibri & 1999 & INTA & - \\
\hline Prointa Don Umberto & 2000 & INTA & - \\
\hline ProInta Elite & 1996 & INTA & - \\
\hline ProInta Federal & 1990 & INTA & - \\
\hline ProInta Gaucho & 2000 & INTA & - \\
\hline ProInta Granar & 1997 & INTA & - \\
\hline ProInta Isla Verde & 1988 & INTA & - \\
\hline ProInta Milenium & 1999 & INTA & - \\
\hline Prointa Molinero & 2000 & INTA & - \\
\hline ProInta Oasis & 1990 & INTA & - \\
\hline ProInta Puntal & 1995 & INTA & - \\
\hline ProInta Real & 1996 & INTA & - \\
\hline
\end{tabular}




\begin{tabular}{|c|c|c|c|}
\hline Prointa Super & 1993 & INTA & - \\
\hline ProInta Supremo & 2000 & INTA & - \\
\hline VPM1 & & & + \\
\hline Balthazar & & & - \\
\hline Thatcher & & & - \\
\hline Soissons & & & \\
\hline
\end{tabular}

(1) According to INASE (2005).

(2) - : absence; + : presence.

(3) ACA = Asociación Cooperativas Argentinas C.L.

${ }^{(4)}$ INTA = Instituto Nacional de Tecnología Agropecuaria.

Triticum ventricosum Ces), is an allotetraploid with the genome designation $\mathrm{D}^{v} \mathrm{D}^{\mathrm{v}} \mathrm{N}^{\mathrm{v}} \mathrm{N}^{\mathrm{v}}$ derived from the hybridization of the $\mathrm{D}$ genome from Ae. tauschii (coss.) Schmal and the $\mathrm{N}$ genome from T. uniaristatum (Vis.) Richter (Kimber and Zhao, 1983). Ae. ventricosa is the source of several disease resistance genes that are of agronomic importance and have been successfully introgressed into wheat. These genes include $L r 37$, which confers resistance in wheat against leaf rust. This gene, located in a 2NS-2AS translocation (Bariana and McIntosh, 1993), was initially introgressed in the winter bread wheat VPM1 (Maia, 1967) and was used by breeders in different parts of the world (Robert et al. 1999; Mesterházy et al. 2000; Seah et al. 2000; Park et al. 2001; Stepien et al. 2003). Rust races with virulence to $\operatorname{Lr} 37$ have been identified in different countries (Mesterházy et al. 2000; Winzeler et al. 2000), but it still provides resistance to a wide range of races and is useful in combination with other resistance genes (Park and McIntosh, 1994; Park et al. 2001; Kolmer et al. 2005).

Greater knowledge on the identity of rust resistance genes present in cultivars that can be used as donors of resistance in wheat breeding programs could greatly improve the efficiency of developing resistant cultivars by using these genes per se or by stacking different resistant genes in a given cultivar (Sawhney and Joshi, 1996). In this context, there are no reports about the presence, frequency and origin of Lr37 in Argentinean wheat cultivars. Resistance gene postulation is a rapid method to hypothesize which resistance genes are present in a host genotype (Loegering et al. 1971). It is based on the gene-for-gene specificity between host resistance genes and pathogen avirulence genes. Host genotypes are evaluated with a wellcharacterized collection of pathogen isolates with different avirulence gene combinations. However, gene postulation can be complicated by interactions between resistance genes and it is best suited for resistance genes that are clearly expressed at the seedling stage (Kolmer, 1996). Resistance genes could also be postulated by testing host genotypes with DNA-based markers linked to resistant genes. This alternative approach overcome some of the problems associated with traditional gene postulation, such as gene interactions and the plant stage of gene expression
(McCartney et al. 2005). For this reason, the objective of this work was to determine the presence of $L r 37$ resistance gene in a sample of 88 wheat cultivars registered in Argentina during the last 15 years by means of a molecular marker which is diagnostic of it.

\section{MATERIALS AND METHODS}

\section{Plant Materials}

Eighty eight cultivars of bread wheat registered in Argentina from 1990 to 2005 were used. These materials represent more than $80 \%$ of the commercialized cultivars in Argentina during the last 15 years by eight different companies and institutions (Table 1). The cultivars Thatcher and Soisson were used as negative controls and VPM1 and Balthazar as positive controls, since both of them carry Lr37 (Park et al. 2001). Seeds of these genetics materials were supplied by G. Vrdoljak and P. Paulucci from the Wheat Breeding Program of Nidera S.A.

\section{DNA Isolation}

Leaf material was collected from at least 20 different plants of each genotype. DNA was extracted from these bulked samples using a standard SDS protocol (Dellaporta et al. 1983).

\section{PCR analysis}

Two pairs of primers were included in each PCR reaction. The primers VENTRIUP-LN2 developed by Helguera et al. (2003) were used to detect the 2NS fragment from Ae. ventricosa, that yield a 259-bp band. The primers for the microsatellite marker GWM400 (Röder et al. 1998) were used to evaluate the quality of the DNA and the presence of PCR reaction inhibitors. These last primers amplify a fragment of about 150-bp.

PCR reaction mixes contained $80 \mathrm{ng}$ of wheat genomic DNA, $0.2 \mu \mathrm{M}$ of each primer (Table 2), $200 \mu \mathrm{M}$ of each dNTP, 1X PCR Buffer containing $50 \mathrm{mM} \mathrm{KCl,} 10 \mathrm{mM}$ Tris-HCl pH 9.0, 0.1\% Triton X-100, $1.5 \mathrm{mM} \mathrm{MgCl}_{2} ; 1$ unit Taq DNA Polymerase (Biotools) in a total volume of 
$25 \mu \mathrm{L}$. Cycling conditions consisted of 3 min denaturation at $95^{\circ} \mathrm{C}$ follow by 30 cycles of $45 \mathrm{sec}$ denaturation at $94^{\circ} \mathrm{C}$, annealing at $65^{\circ} \mathrm{C}$ for $30 \mathrm{sec}$, and 1 min extension at $72^{\circ} \mathrm{C}$, and finally $7 \mathrm{~min}$ extension at $72^{\circ} \mathrm{C}$ on a Biorad thermocycler. Amplification products $(10 \mu \mathrm{L} / \mathrm{lane})$ were separated on a standard $2 \%$ agarose gel in $1 \mathrm{X}$ TBE buffer, at constant voltage power for about 2 hrs. A 25 bp ladder (Promega) was used to estimate the size of each amplified DNA fragment. After electrophoresis, the gel was stained with ethidium bromide and bands were visualized with UV light.

Table 2. Primer names and sequences.

\begin{tabular}{|l|l|}
\hline Name & Sequence $\mathbf{( 5}^{\prime} \mathbf{- 3}^{\prime} \mathbf{}^{\mathbf{}}$ \\
\hline Ventriup $^{(1)}$ & AGG GGC TAC TGA CCA AGG CT \\
\hline LN2 $^{(1)}$ & TGC AGC TAC AGC AGT ATG TAC ACA AAA \\
\hline Xgwm400-F $^{(2)}$ & GTG CTG CCA CCA CTT GC \\
\hline Xgwm400-R $^{(2)}$ & TGT AGG CAC TGC TTG GGA G \\
\hline
\end{tabular}

\section{RESULTS AND DISCUSSION}

Robert et al. (1999) and Seah et al.(2001) developed PCR markers for the identification of the cluster of resistance genes Sr38-Yr17-Lr37, but these markers were not publicly available. Helguera et al. (2003) developed the first public PCR marker for this chromosome fragment which was used in this work. Since the long chromosomal fragment (25-38 $\mathrm{cM}$ ) from Ae. ventricosa does not recombine with the bread wheat chromosomes, the resistance genes located in the 2NS segment are transferred together and are completely linked to markers developed within this segment (Robert et al. 1999; Helguera et al. 2003).

The 259-bp PCR product from primers VENTRIUP-LN2, which is diagnostic for the $2 \mathrm{~N}$ chromosome fragment, was observed in 4 out of 88 cultivars tested and in the positive checks VPM1 and Balthazar (Table 1). The other cultivars and the two negative controls, on the other hand, did not amplify this diagnostic fragment. In fact, all of them presented only one PCR amplification product corresponding to different alleles of the microsatellite locus Xgwm400, used as an internal control of the PCR reaction.

The four cultivars which carry the translocated 2NS-2AS chromosome (Baguette 10, Baguette 12, Baguette 5 Sur and Baguette 11 Premium) were registered by the same breeding company (Nidera S.A.) in 1999, 2001 and 2004, and all of them have European germplasm in their genealogy. This is not surprisingly because VPM1 (the original line which carry the 2NS chromosome segment) was developed and used intensively in France and other European countries. As a matter of fact, the Lr37 resistant gene was identified, by means of gene postulation or molecular markers, in different cultivars registered in UK, the Czech Republic, France and Poland (Winzeler et al.
2000; Singh et al. 2001; Blaszczyk et al. 2004). The frequency of this gene in UK cultivars, for example, reached 26.6\% by 2001 (Park et al. 2001). Cultivars registered by other companies and institutions traced their origin to Argentinean, Uruguayan, Brazilian and Mexican wheat germplasm, where the deployment of the gene Lr37 was not reported.

Research efforts to breed cereals for resistance to rust diseases have identified resistance genes expressed throughout the entire growth cycle of the plant (seedling resistance genes), and genes which confer resistance to avirulent pathotypes only in post-seedling growth stages (adult plant resistance, APR; Park and McIntosh, 1994). Lr37 is an APR gene which shows certain level of resistance in seedlings at temperatures below $20^{\circ} \mathrm{C}$ (Park and McIntosh, 1994; Kolmer, 1996). At temperatures above $20^{\circ} \mathrm{C} \mathrm{Lr37}$ is ineffective at seedling growth stages, acting as classical APR genes in becoming effective at post-seedling growth stages (Park and McIntosh, 1994). It has been reported that this gene shows a better response than the more common APR genes Lr12 or Lr13 when tested with 20 isolates belonging to 13 different races of $P$. triticina from Uruguay and Argentina (Germán, 2003), with 49 isolates representing the most common virulence phenotypes of this pathogen in USA (Kolmer et al. 2005) and with 15 isolates from Canada (Kolmer, 1997).

Wheat lines released by the CIMMYT program are selected for high levels of resistance to leaf rust (Braun et al. 1996; Sayre et al. 1998). Gene postulation studies of CIMMYT lines indicated the presence of $L r 1, L r 3, L r 3 b g, L r 10$, Lr14a, Lr17, Lr19, Lr23, Lr26, Lr27 and Lr31 (Kolmer, 1996). Since this germplasm is intensively used by Argentinean breeding programs, all of these genes may be present in Argentinean cultivars. In addition, many spring wheat developed in South America possibly have Lr13 and/or Lr34 (Kolmer, 1996). Other wheat developed in South America have been valuable sources of leaf rust resistance. Dyck and co-workers (cited by Kolmer, 1996) isolated $L r 3$ from Sinvalocho, Lr3ka from Klein Aniversario, Lr3bg from Bage, Lr11 from El Gaucho, Lr14b from Rafaela, Lr17 from Klein Lucero and Lr30 and Lr34 from Terenzio. Antonelli (2003) reported the presence of $L r 3 a, L r 10, L r 23$ and $L r 26$ in ProINTA Oasis, Lr14a in ProINTA Federal and Lr24 in Trigal 800 and derivatives.

To the best of our knowledge this is the first report of the presence of $\operatorname{Lr37}$ in registered South American cultivars. Its identification in high yielding and adapted cultivars contribute to enrich an already broad genetic base for resistance to leaf rust in Argentinean wheat germplasm. Moreover, taking into account that $\operatorname{Lr} 37$ is linked to the genes Sr38, Yr17 and Cre5 (Bariana and McIntosh, 1993; Jahier et al. 1996; Seah et al. 2000) which confer resistance to stripe rust (Puccinia striiformis West. F. sp. tritici), stem rust (Puccinia graminis Pers. f.sp. tritici Eriks and E. Henn.) and cereal cyst nematode (Heterodera avenae Woll.) respectively, indicates that this introgressed 
chromosome fragment can be highly useful in developing new wheat varieties.

\section{REFERENCES}

ANTONELLI, E.F. La Roya de la Hoja (Puccinia triticina Erikss.). In: Seminario Internacional: Resistencias a Royas en Trigo $\left(16^{\text {th }}-17^{\text {th }}\right.$ July, 2003, La Estanzuela. Uruguay). 2003. p 14.

BARIANA, H.S. and MCINTOSH, R.A. Cytogenetic studies in wheat XIV. Location of rust resistance genes in VPM1 and their genetic linkage with other disease resistance genes in chromosome 2A. Genome, 1993, vol. 36, no. 3, p. 476-482.

BLASZCZYK, Lidia; CHELKOWSKI, Jerzy; KORZUN, Victor; KRAIC, Jan; ORDON, Frank; OVESNA, Jaroslava; PURNHAUSER, Laszlo; TAR, Melinda and VIDA, Gyula. Verification of STS markers for leaf rust resistance genes of wheat by seven European laboratories. Cellular and Molecular Biology Letters, 2004, vol. 9, no. 4b, p. 805-817.

BRAUN, Hans-Joachim; RAJARAM, Sanjaya and VAN GINKEL, Maarten. CIMMYT's approach to breeding for wide adaptation. Euphytica, January 1996, vol. 92, no. 1-2, p. 175-183.

DELLAPORTA, S.L.; WOOD, J. and HICKS, J.B. A plant DNA minipreparation: Version II. Plant Molecular Biology Reporter, 1983, vol. 1, p. 19-21.

FRIEBE, B.; JIANG, J.; RAUPP, W.J.; MCINTOSH, R.A. and GILL, B.S. Characterization of wheat-alien translocations conferring resistance to diseases and pests: current status. Euphytica, January 1996, vol. 91, no. 1, p. 59-87.

GERMAN, S. Relevamiento de razas de Puccinia triticina en Uruguay y Argentina 20002002. In: Seminario Internacional: Resistencias a Royas en Trigo. $\left(16^{\text {th }}-17^{\text {th }}\right.$ July, 2003, La Estanzuela. Uruguay). 2003. p 14.

HELGUERA, M.; KHAN, I.A.; KOLMER, J.; LIJAVETZKY, D.; ZHONG-QI, L. and DUBCOVSKY, J. PCR assays for the Lr37-Yr17-Sr38 cluster of rust resistance genes and their use to develop isogenic hard red spring wheat lines. Crop Science, September-October 2003, vol. 43, no. 5, p. 1839-1847.

INASE. Dirección de Registro de Variedades. Registro Nacional de la Propiedad de Cultivares y Catálogo de Variedades [Online]. 2005. Available from Internet: http://www.mecon.gov.ar

JAHIER, J.; TANGUY, A.M.; ABÉLARD, P. and RIVOAL, R. Utilization of deletions to localize a gene for resistance to the cereal cyst nematode, Heterodera avenue, on an Aegilops ventricosa chromosome. Plant Breeding,
September 1996, vol. 115, no. 4, p. 282-284.

JOHNSON, R. Classical plant breeding for durable resistance to diseases. Journal of Plant Pathology, 2000, vol. 82, no. 1, p. 3-7.

KIMBER, G. and ZHAO, Y.H. The D genome of the Triticeae. Canadian Journal of Genetics and Cytology, 1983, vol. 25, p. 581-589.

KOLMER, J.A. Genetics of resistance to wheat leaf rust. Annual Review of Phytopathology, September 1996, vol. 34, p. 435-455.

KOLMER, J.A. Virulence in Puccinia recondita f. sp. tritici isolates from Canada to genes for adult-plant resistance to wheat leaf rust. Plant Disease, March 1997, vol. 81, no. 3, p. 267-271.

KOLMER, J.A.; LONG, D.L. and HUGHES, M.E. Physiologic specialization of Puccinia triticina on wheat in the United States in 2003. Plant Disease, November 2005, vol. 89, no. 11, p. 1201-1206.

LOEGERING, W.Q.; MCINTOSH, R.A. and BURTON, C.H. Computer analysis of disease data to derive hypothetical genotypes for reaction of host varieties to pathogens. Canadian Journal of Genetics and Cytology, 1971, vol. 13, p. 742-748.

MAIA, N. Obtention des blés tendres resistants au pietinverse par croisements interspecifiques blés $\mathrm{X}$ Aegilops. Comptes Rendus des Séances de l'Académie d'Agriculture de France, 1967, vol. 53, p. 149-154.

MCCARTNEY, C.A.; SOMERS, D.J.; MCCALLUM, B.D.; THOMAS, J.; HUMPHREYS, D.G.; MENZIES, J.G. and BROWN, P.D. Microsatellite tagging of the leaf rust resistance gene Lr16 on wheat chromosome 2BSc. Molecular Breeding, May 2005, vol. 15, no. 4, p. 329-337.

MESTERHÁZY, A.; BARTOS, P.; GOYEAU, H.; NIKS, R.E.; CSOSZ, M.; ANDERSEN, O.; CASULLI, F.; ITTU, M.; JONES, E., MANISTERSKI, J.; MANNINGER, K.; PASQUINI, M.; RUBIALES, D.; SCHACHERMAYR, G.; STRZEMBICKA, A.; SZUNICS, L.; TODOROVA, M.; UNGER, O.; VANCO, B.; VIDA, G. and WALTHER, U. European virulence survey for leaf rust in wheat. Agronomie, November 2000, vol. 20, no. 7, p. 793-804.

PARK, R.F. and MCINTOSH, R.A. Adult plant resistances to Puccinia recondita $f$. sp. tritici in wheat. New Zealand Journal of Crop and Horticulture Science, February 1994, vol. 22, p. 151-158.

PARK, R.F.; GOYEAU, H.; FRIEDRICH, G.F.; BARTOS, P. and ZELLER, F.J. Regional phenotypic diversity of Puccinia triticina and wheat host resistance in western Europe, 1995. Euphytica, January 2001, vol. 122, no. 1, p. 
$113-127$.

ROBERT, Oliver; ABELARD, Christine and DEDRYVER, Françoise. Identification of molecular markers for the detection of the yellow rust resistance gene $\operatorname{Yr} 17$ in wheat. Molecular Breeding, March 1999, vol. 5, no. 2, p. 167-175.

RÖDER, Marion S.; KORZUM, Victor; WENDEHAKE, Katja; PLASCHKE, Jens; TIXIER, Marie-Hélène; LEROY, Philippe and GANAL, Martin W. A microsatellite map of wheat. Genetics, August 1998, vol. 149, no. 4, p. 20072023.

SAYRE, K.D.; SINGH, R.P.; HUERTA-ESPINO, J. and RAJARAM, S. Genetic progress in reducing losses to leaf rust in CIMMYT-derived Mexican spring wheat cultivars. Crop Science, May 1998, vol. 38, no. 3, p. 654-659.

SAWHNEY, R.N. and JOSHI, B.C. Genetic research as the valid base of strategies for breeding rust resistant wheats. Genetica, May 1996, vol. 97, no. 3, p. 243-254.

SEAH, S.; SPIELMEYER, W.; JAHIER, J.; SIVASITHAMPARAM, K. and LAGUDAH, E.S. Resistance gene analogs within an introgressed chromosomal segment derived from Triticum ventricosum that confers resistance to nematode and rust pathogens in wheat. Molecular Plant-Microbe Interactions, March 2000, vol. 13, no. 3, p. 334-341.

SEAH, S.; BARIANA, H.; JAHIER, J.; SIVASITHAMPARAM, K. and LAGUDAH, E.S. The introgressed segment carrying rust resistance genes $\mathrm{Yr} 17$, Lr37 and Sr38 in wheat can be assayed by a cloned disease resistance gene-like sequence. Theoretical and Applied Genetics, March 2001, vol. 102, no. 4, p. 600-605.

SINGH, D.; PARK, R.F. and MCINTOSH, R.A. Postulation of leaf (brown) rust resistance genes in 70 wheat cultivars grown in the United Kingdom. Euphytica, January 2001, vol. 120, no. 2, p. 205-218.

STEPIEN, Lukasz; GOLKA, Lidia and CHELKOWSKI, Jerzy. Leaf rust resistance genes of wheat: identification in cultivars and resistance sources. Journal of Applied Genetics, 2003, vol. 44, no. 2, p. 139-149.

VALKOUN, J.J. Wheat pre-breeding using wild progenitors. Euphytica, May 2001, vol. 119, no. 1-2, p. 1723.

WINZELER, Michael; MESTERHAZY, Akos; PARK, Robert F.; BARTOS, Pavel; CSOSZ, Maria; GOYEAU, Henriette; ITTU, Mariana; JONES, Elwyn; LOSCHENBERGER, Franziska; MANNINGER, Klara; PASQUINI, Marina; RICHTER, Klaus; RUBIALES, Diego; SCHACHERMAYR, Gabriele; STRZEMBICKA, Anna; TROTTET, Maxime; UNGER, Otto; VIDA, Gyula and WALTHER, Ursula. Resistance of European winter wheat germplasm to leaf rust. Agronomie, November 2000, vol. 20, no. 7, p. 783-792. 